\title{
Pekin Duck Strain and Housing System Affect Chemical Composition, Fatty Acid Profile, and The Extent of Lipid and Protein Oxidation in Meat
}

\section{Marija Starčević ( $\nabla$ marijadok@gmail.com )}

Univerzitet u Beogradu Fakultet veterinarske medicine https://orcid.org/0000-0002-0857-5218

\section{Hava Mahmutović}

JU Univerzitet u Tuzli Tehnoloski Fakultet

Nataša Glamočlija

Univerzitet u Beogradu Fakultet veterinarske medicine

\section{Branislav Baltić}

Institut za Higijenu I Tehnologiju Mesa

\section{Milka Popović}

Univerziteta u Novom Sadu Medicinski Fakultet

\section{Radmila Mitrović}

Institut za Higijenu I Tehnologiju Mesa

\section{Radmila Marković}

Univerzitet u Beogradu Fakultet veterinarske medicine

Jelena Janjić

Univerzitet u Beogradu Fakultet veterinarske medicine

\section{Milica Glišić}

Univerzitet u Beogradu Fakultet veterinarske medicine

\section{Milan Ž. Baltić}

Univerzitet u Beogradu Fakultet veterinarske medicine

\section{Research}

Keywords: duck, chemical composition, fatty acid composition, lipid peroxidation, protein carbonyl content, thigh, breast

Posted Date: March 1st, 2021

DOI: https://doi.org/10.21203/rs.3.rs-248355/v1

License: (a) (i) This work is licensed under a Creative Commons Attribution 4.0 International License. Read Full License 


\section{Abstract}

Background: Genetics and rearing system are important for meat quality. However, few studies were conducted on genetics and housing system and their relationship with chemical composition and oxidation processes in Pekin duck meat. In order to investigate the effect of different strains and housing systems on chemical composition, fatty acid profile and the content of lipid and protein oxidation products in breasts and thighs of Pekin ducks, we used a total of 40 49-day-old Pekin ducks of two strains (STAR 53 medium hybrid and SM3 heavy hybrid) reared in two housing systems (intensive vs. semi-intensive).

Results: Duck strain affected the contents of moisture and protein in breasts and fatty acid composition in breasts and thighs. STAR 53 ducks had a lower polyunsaturated fatty acids (PUFA) to saturated fatty acids (SFA) ratio and level of lipid peroxidation measured in frozen thighs than SM3 ducks. Chemical composition of meat was not affected by housing system. Rearing conditions influenced fatty acid composition of breasts and thighs. In intensively reared ducks, higher total n-3 PUFA content and PUFA to SFA ratio, and lower n-6 to n-3 PUFA ratio and atherogenicity index were found in thighs than in ducks that had access to land outside. Moreover, rearing conditions had significant effects on lipid peroxidation level and protein carbonyl content in meat. In intensively reared birds, fresh samples of thigh meat and frozen samples of breasts and thighs had higher level of lipid peroxidation than in semi-intensively reared ducks. Contents of protein carbonyls in fresh samples of breasts and thighs were higher in birds reared in the intensive system than in ducks reared in the semi-intensive housing system.

Conclusions: These results suggest that duck strain affects fatty acid composition of meat, where SM3 ducks had more favorable fatty acid profiles than STAR 53 ducks. Moreover, housing system influenced meat quality. Intensively reared ducks had a more desirable fatty acid profile of meat, but it was more prone to lipid and protein oxidation than meat from ducks that had open access to land.

\section{Background}

Consumer concerns on the quality and healthfulness of meat and meat products have greatly increased during past decades [1]. Nutritional value of meat depends on many factors, but mostly on protein and vitamin content, as well as on content and composition of fat [2]. Lipids are important for human nutrition, since they provide energy and contain essential fatty acids involved in biological processes of the body [2] and in a balanced ratio in diet, minimize adverse health issues [3]. It was proved that diets rich in monounsaturated fatty acids (MUFA) and polyunsaturated fatty acids (PUFA) can decrease the risks of cardiovascular disease and diabetes in humans [4]. Furthermore, fatty acids are gaining increasing importance in animal nutrition, not only for improving the health, but also the productivity of animals [3]. On the other hand, PUFA provide the substrate for the formation of lipid oxidation products, usually measured by the content of 2-thiobarbituric acid reactive substances (TBARS) [4]. Furthermore, meat proteins can undergo oxidation resulting in the formation of protein carbonyl compounds (PCC). Protein oxidation can occur directly by the reaction of proteins with reactive oxygen species, or indirectly by reaction with lipid oxidation products [4]. Both lipid and protein oxidation products are accompanied by off-flavors and odors in meat that decrease meat quality, nutritional value, and consumer acceptance of meat $[3,5]$. 
In recent decades duck meat consumption has increased worldwide due to its high nutritive value, in particular due to high percentage of proteins and lipids, and high content of red muscle fibers in meat $[4,6]$. Moreover, duck meat is a good source of polyunsaturated fatty acids, especially n-6 PUFA, has a favorable amino acid profile, and, compared to other species, contains high level of Heme-Fe [6, 7]. However, these characteristics of duck meat provide favorable conditions for lipid and protein oxidation, measured by higher contents TBARS and PCC than in other species [7]. Since the extent of oxidation processes are dependent on the fatty acid profile of meat [7], many studies investigated fatty acid profiles of different genotypes of duck, suggesting that genetic factors could influence fatty acid composition of meat $[4,8,9$, $10,11]$. Considering that Pekin duck has many desirable characteristics, such as extraordinary body size, excellent muscle yield performance, and high intramuscular fat content [4], it is the preferred breed for commercial meat production. However, Pekin duck has a high susceptibility to environmental stress, as affected by housing conditions [12]. Many studies indicated that housing system is one of the numerous non-genetic factors that can greatly affect animal health and welfare, and meat and carcass quality [13]. Since production of Pekin duck meat has become more intensive in recent decades, it is necessary to investigate how various duck production systems affect meat quality. To the best of our knowledge, there are few data regarding effects of different Pekin strains and rearing systems on fatty acid profile and the level of lipid and protein oxidation in duck meat. Therefore, the objective of this study was to determine the impacts of different Pekin strains (STAR 53 medium hybrid vs. SM3 heavy hybrid) and rearing systems (intensive vs. semi-intensive) on chemical composition, fatty acid profile, and the extent of lipid and protein oxidation in meat.

\section{Methods}

\section{Animals, housing, experimental diets, and study duration}

A total of 40 one-day-old Pekin ducklings of two strains (20 ducklings of STAR 53 medium hybrid hatched from parents imported from the French company, Grimaud Frères, and 20 ducklings of SM3 heavy hybrid hatched from parents imported from Cherry Valley Farms Ltd (Great Britain)) were used in the study over 49 days. The ducklings from both strains were divided randomly in two groups that were split between the two housing systems (intensive vs. semi-intensive), so each system contained 10 STAR 53 medium hybrid ducklings and 10 SM3 heavy hybrid ducklings. In the intensive system, birds were reared in a complete confinement system on a floor (stocking density $=0.15 \mathrm{~m}^{2} / \mathrm{head}$ ), while in the semi-intensive system, ducks had access to land outside (stocking density $=0.38 \mathrm{~m}^{2} / \mathrm{head}$ ). The study was conducted during April and May, when the average daily temperature was $14.7^{\circ} \mathrm{C}$. From the beginning of the study, ducklings were housed at $33^{\circ} \mathrm{C}$, and then room temperature was gradually decreased by $3^{\circ} \mathrm{C}$ each week until the final temperature of $22^{\circ} \mathrm{C}$ was reached in the complete confinement housing system. In the semi-intensive housing system that enabled access to land outside, birds were kept enclosed in a barn during the night. Ducklings were not identified by sex at any time during the study, so we assumed an approximately equal ratio of males and females was distributed in the experimental groups. Considering the differences in duck strain (STAR 53 medium hybrid vs. SM3 heavy hybrid) and rearing system (intensive vs. semi-intensive), four experimental groups were formed, each containing 10 animals. Pen floors were covered with straw, 
and birds were provided with fresh drinking water and feed ad libitum. Uneaten feed was removed at the end of each day and replaced with fresh feed.

From the start of the study, animals were fed with the same diets that were formulated to meet the maintenance and growth requirements of animals [14] (Table 1). Diets fed from days 1 to 49 were starter (days 1-21), grower (days 22-35) and finisher (days 36-49). All components of the diets were analyzed for dry matter [15], crude protein [16], crude fat [17], crude fiber [18], calcium [19], and phosphorus [20] (Table 1). Percentages of lysine, methionine, and methionine+cysteine in diets presented in Table 1 were calculated based on their contents in feed materials and contents of supplemented DL-methionine and Llysine [21]. Fatty acid composition of the three diets (starter, grower, and finisher) was determined according to the procedure described below and is presented in Table 2 .

At the end of the study, animals were transported in plastic cages to the slaughterhouse. In the slaughterhouse, ducks were electrically stunned and immediately slaughtered by severance of the jugular veins. Animals were processed following standard industrial techniques. After slaughter, carcasses were dissected into basic parts in order to determine chemical composition, fatty acid profile, and the extent of lipid and protein oxidation in breast and thigh meat.

\section{Chemical composition of meat}

Chemical analysis was performed on six breast (M. pectoralis superficialis) and six thigh (M. iliotibialis) meat samples from each experimental group. At $24 \mathrm{~h}$ post mortem, meat samples were dissected from breasts and thighs, packed in polyethylene bags, and kept at $-18^{\circ} \mathrm{C}$ until analyses of moisture [22], lipid [23], protein [24] and collagen contents [25].

\section{Fatty acid composition of diets and meat samples}

Determination of fatty acid profile was performed on all three diets and six breast (M. pectoralis superficialis) and six thigh (M. iliotibialis) meat samples from each experimental group. All samples were homogenized, collected in plastic bags and frozen at $-18^{\circ} \mathrm{C}$. The day before lipid extraction, samples were defrosted overnight at $4{ }^{\circ} \mathrm{C}$. All analyses were performed in duplicate. Extraction of total lipids from homogenized samples for determination of fatty acid profile was carried out by accelerated solvent extraction (ASE 200, Dionex, GmbH, Idstein, Germany) with a mixture of n-hexane and isopropanol (60:40, $\mathrm{v} / \mathrm{v}$ ) at $100{ }^{\circ} \mathrm{C}$ and nitrogen pressure of $10.3 \mathrm{Mpa}$ [26]. Before extraction, two glass fiber cellulose filter papers $19.8 \mathrm{~mm}$ (Dionex) were placed at the bottom of each $33 \mathrm{~mL}$ Dionex extraction cell before the cell was consecutively loaded with $2 \mathrm{~g}$ of diatomaceous earth, $2.5 \mathrm{~g}$ of homogenized sample, and $2 \mathrm{~g}$ diatomaceous earth up to the cell top. The loaded cells were then mounted in the carousel of the ASE 200 and subsequently extracted. The extracts were collected and solvent was removed under a stream of nitrogen (Dionex Solvent evaporator 500 ) at $50{ }^{\circ} \mathrm{C}$ until dryness. The fat extracts were kept overnight in a desiccator and weighed. Extracted lipids were converted to fatty acid methyl esters (FAMEs) by using trimethylsulfonium hydroxide [27]. FAMEs were determined by capillary gas chromatography on a Shimadzu 2010 gas chromatograph (Kyoto, Japan) equipped with flame ionization detector and capillary HP-88 column ( $100 \mathrm{~m} \times 0.25 \mathrm{~mm} \times 0.20 \mu \mathrm{m}$, J\&W Scientific, USA). The analysis was performed under 
temperature gradient: $125^{\circ} \mathrm{C}$, rate $10^{\circ} \mathrm{C} / \mathrm{min}$ to $175^{\circ} \mathrm{C}$, hold $10 \mathrm{~min}$, rate $5^{\circ} \mathrm{C} / \mathrm{min}$ to $210^{\circ} \mathrm{C}$, hold $5 \mathrm{~min}$, and rate $2{ }^{\circ} \mathrm{C} / \mathrm{min}$ to final temperature of $230^{\circ} \mathrm{C}$. Temperature of the injector and detector were $250{ }^{\circ} \mathrm{C}$ and $280^{\circ} \mathrm{C}$, respectively. The carrier gas was nitrogen at a flow rate of $1.33 \mathrm{~mL} / \mathrm{min}$, and injector split ratio was 1:50. Nitrogen was used as a make-up gas at $30 \mathrm{~mL} / \mathrm{min}$ flow rate. Injected volume was $1 \mu \mathrm{L}$ and total analysis lasted $50.5 \mathrm{~min}$. The chromatographic peaks in the samples were identified by comparing relative retention times of FAME peaks with peaks in Supelco 37 Component FAME mix standard (Supelco, Bellefonte, USA). Quantification of fatty acids was determined relative to an internal standard, heneicosanoic acid methyl ester. The level of fatty acids was expressed as a percentage (\%) of the total identified fatty acids. After determination of fatty acid profile of breasts and thighs, the following ratios of fatty acid classes were calculated: MUFA to saturated fatty acids (SFA), PUFA to SFA, unsaturated fatty acids (UFA) to SFA, and n-6 to n-3 PUFA.

\section{Lipid oxidation}

The extent of lipid peroxidation was evaluated as 2-thiobarbituric acid reactive substances (TBARS) by the modified method of Botsoglou et al. [28] on 10 fresh and 10 frozen samples of breast (M. pectoralis superficialis) and thigh (M. iliotibialis) meat of each experimental group. 2-Thiobarbituric acid (TBA) reacted with malondialdehyde (MDA), as a product of lipid oxidation, which resulted in a color compound measured spectrophotometrically. TBARS values of fresh samples were determined at $24 \mathrm{~h}$ post mortem, while frozen samples were stored at $-20^{\circ} \mathrm{C}$ for 6 weeks and after defrosting at $4{ }^{\circ} \mathrm{C}$, TBARS values were measured. For TBARS determination, $2.0 \mathrm{~g}$ of sample was stirred with TRIS buffer (100 mM TRIS; $0.1 \mathrm{mM}$ EDTA; $0.1 \%$ triton X-100; $\mathrm{pH} 7.8$ ) in a 1:5 (sample:TRIS buffer) ratio and then homogenized at $3500 \mathrm{~g}$ for 10 min at $2{ }^{\circ} \mathrm{C}$. Subsequently, the homogenized sample $(0.5 \mathrm{~mL})$ was stirred with $1 \mathrm{~mL}$ of $20 \%(\mathrm{w} / \mathrm{v})$ trichloroacetic acid (TCA) and then homogenized at $3500 \mathrm{~g}$ for $10 \mathrm{~min}$. The precipitated fraction was used for determination of protein carbonyl content. Equal amounts $(0.5 \mathrm{~mL})$ of supernatant and TBA reagent were mixed. TBA reagent was fresh prepared every day and contained $0.5 \%(\mathrm{w} / \mathrm{v})$ TBA dissolved in $0.33 \mathrm{M}$ $\mathrm{HCl}$. To prevent further peroxidation during heating, $5 \mu \mathrm{L}$ of $2 \%(\mathrm{w} / \mathrm{v})$ butylated hydroxytoluene (BHT) dissolved in absolute ethanol was added to the mixture. The mixture was heated at $95^{\circ} \mathrm{C}$ for $60 \mathrm{~min}$ and cooled by placing on ice. Equal amounts of butanol and previously prepared mixture were mixed and then centrifuged at 3,500 g for $10 \mathrm{~min}$. Absorbance of the upper butanol layer was read at $532 \mathrm{~nm}$ against a sample blank (containing all components excluding TBA) and a reagent blank (containing all components excluding sample). All tests and controls were prepared in triplicate. The results were quantified as malondialdehyde equivalents (mg MDA/kg sample).

\section{Protein oxidation}

Protein oxidation was measured by estimating the protein carbonyl content. Precipitated fractions obtained from the previously described TBARS analysis were used to measure protein carbonyl content on 10 fresh and 10 frozen samples of breast (M. pectoralis superficialis) and thigh (M. iliotibialis) meat of each experimental group by a modified method of Dalle-Donne et al. [29]. Precipitated fractions were stirred with a solution of $10 \mathrm{mM}$ 2,4-dinitrophenylhydrazine (DNPH) dissolved in $2 \mathrm{M} \mathrm{HCl}$ to form a stable 2,4dinitrophenyl (DNP) hydrazone product, while sample blanks contained $2 \mathrm{M} \mathrm{HCl}$ without DNPH. Mixtures 
were intensively stirred and then incubated in the dark at room temperature for $60 \mathrm{~min}$ with vortexing every $10 \mathrm{~min}$. Thereafter, mixtures were centrifuged at $3,500 \mathrm{~g}$ for $10 \mathrm{~min}$ to obtain precipitate. The supernatants were discarded and precipitated fractions were washed with $20 \%$ TCA, and then washed three times with 2 $\mathrm{mL}$ of ethanol:ethyl acetate $(1: 1, \mathrm{v} / \mathrm{v})$. Between each washing, precipitates were centrifuged at $3,500 \mathrm{~g}$ for $10 \mathrm{~min}$. Precipitated fractions were resuspended in $1 \mathrm{~mL}$ of $6 \mathrm{M}$ guanidine hydrochloride dissolved in $2 \mathrm{M}$ $\mathrm{HCl}\left(\mathrm{pH}\right.$ 2.3) and incubated in a water bath at $37^{\circ} \mathrm{C}$ for $15 \mathrm{~min}$ with occasional vortexing. Carbonyl content was determined from the absorbance at $375 \mathrm{~nm}\left(e=22000 \mathrm{M}^{-1} \mathrm{~cm}^{-1}\right)$ against a sample blank (containing all components excluding DNPH). Due to protein loss (10-20\%) during washing, the protein content was measured in each sample blank by reading absorbance at $280 \mathrm{~nm}$. The protein content was determined by comparing the absorbance of the samples to the absorption coefficient from a standard curve (0.25-2.0 $\mathrm{mg} / \mathrm{mL}$ ) using bovine serum albumin dissolved in $6 \mathrm{M}$ guanidine hydrochloride and $2 \mathrm{M} \mathrm{HCl}(\mathrm{pH} 2.3)$. The carbonyl content was expressed as $\mathrm{nmol} / \mathrm{mg}$ of proteins.

\section{Determination of atherogenicity index (Al), thrombogenicity index (TI) and hypocholesterolemic to hypercholesterolemic fatty acids ratio $(\mathrm{H} / \mathrm{H})$}

The atherogenicity index (Al) was calculated from the ratio of the sum of the main saturated fatty acids (considered as pro-atherogenic) and that of the main classes of unsaturated fatty acids (considered as anti-atherogenic) according to the following equation [30]:

$\mathrm{Al}=(\mathrm{C} 12: 0+(4 \times \mathrm{C} 14: 0)+\mathrm{C} 16: 0) /\left(\sum \mathrm{n}-3\right.$ PUFA $+\sum \mathrm{n}-6$ PUFA $\left.+\sum M U F A\right)$

The thrombogenicity index $(\mathrm{TI})$ indicates a tendency for clots to form in the blood vessels and was calculated from the ratio of pro-thrombogenetic (saturated) and the anti-thrombogenetic fatty acids (MUFA, PUFA n-6 and PUFA n-3) according to the following equation [30]:

$\mathrm{TI}=(\mathrm{C} 14: 0+\mathrm{C} 16: 0+\mathrm{C} 18: 0) /\left(0.5 \times \sum\right.$ MUFA $+0.5 \times \sum \mathrm{n}-6$ PUFA $+3 \times \sum \mathrm{n}-3$ PUFA $+\sum \mathrm{n}-3$ PUFA $/ \sum \mathrm{n}-6$ PUFA)

The hypocholesterolemic to hypercholesterolemic fatty acid ratio $(\mathrm{H} / \mathrm{H})$ indicates functional activity of fatty acids in the metabolism of lipoprotein regarding plasma cholesterol transport and the risk of cardiovascular disease. The ratio of hypocholesterolemic to hypercholesterolemic fatty acids $(H / H)$ was calculated according to Paszczyk et al. [31]:

$H / H=(C 18: 1 n-9 C+C 18: 2 n-6+C 18: 3 n-3) /(C 12: 0+C 14: 0+C 16: 0)$

\section{Statistical analysis}

Statistical analysis of the results was conducted with GraphPad Prism software version 6.00 for Windows (GraphPad Software, San Diego, CA, USA, www.graphpad.com). Two-way analysis of variance (ANOVA) with Tukey's multiple comparison test was performed to test the effect of duck strain (STAR 53 medium hybrid vs. SM3 heavy hybrid) and housing system (intensive vs. semi-intensive) as the main effects, and their interactions on chemical composition, TBARS and protein carbonyl values, fatty acid composition, and $\mathrm{Al}, \mathrm{Tl}$, and $\mathrm{H} / \mathrm{H}$ of breasts and thighs of Pekin ducks. The means of the breasts and thighs within the same 
duck strain and housing system were subjected to t-test to determine significant differences between compared muscles. All parameters were described by means and standard error of means (SEM). Values of $P<0.05$ were considered significant.

\section{Results}

\section{Chemical characteristics, TBARS and protein carbonyl values of meat}

The effects of duck strain and housing system, as well as their interactions on chemical composition, TBARS, and protein carbonyl values in meat are presented in Table 3. Duck strain affected chemical composition of breasts, as higher moisture content $(P<0.05)$ and lower protein content $(P<0.05)$ were determined in breasts of STAR 53 ducks than in SM3 ducks. Chemical composition was not affected by rearing conditions. Furthermore, in all experimental groups, higher protein content $(P<0.01)$ and lower lipid content $(P<0.01)$ were determined in breasts than in thighs.

Duck strain affected TBARS values of frozen thigh meat, where higher TBARS values were determined in SM3 ducks than in STAR 53 ducks $(P<0.01)$. Rearing conditions had significant effects on TBARS values. In fresh samples of thigh meat and frozen samples of breasts and thighs, TBARS values were higher $(P<0.01)$ in intensively reared birds than in ducks reared in the semi-intensive housing system. Higher contents of TBARS values were found in fresh breast meat of all experimental groups than in thigh meat $(P<0.01)$. The content of protein carbonyls in fresh breast and thigh meats was affected by rearing conditions, where higher values of protein carbonyls were found in birds reared in intensive system than in ducks reared in semi-intensive housing system $(P<0.05)$. Furthermore, fresh breast meat of SM3 ducks reared in semiintensive system had a higher content of protein carbonyls than fresh thigh meat $(P<0.05)$. There were no significant interactions between duck strain and housing system on the examined parameters.

\section{Fatty acid profile of meat}

The effects of duck strain and rearing system on fatty acid composition, $\mathrm{Al}, \mathrm{Tl}$, and $\mathrm{H} / \mathrm{H}$ ratio in breasts and thighs are presented in Tables 4 and 5, respectively. Duck strain had no influence on fatty acid composition of breasts, except for eicosenoic acid (C20:1n9), where higher contents were found in breasts of STAR 53 hybrid than in SM3 hybrid Pekin ducks $(P<0.05)$. The analysis revealed that rearing conditions affected contents of lauric (C12:0) and linoleic acid (C18:2n6c). Higher percentages of the aforementioned fatty acids were found in birds kept indoors than in ducks reared in the housing system with open access to land $(P<0.05)$. On the contrary, contents of elaidic (C18:1n9t) and cis vaccenic acid (C18:1n11c) were lower in ducks reared in intensive housing than in ducks reared in semi-intensive housing $(P<0.05)$. Significant interactions were found between duck strain and housing system on contents of myristoleic (C14:1), cis vaccenic (C18:1n11c), trans octadecadienoic acid (C18:2n6), MUFA to SFA ratio, UFA to SFA ratio, TI, and $\mathrm{H} / \mathrm{H}$ ratio of breasts $(P<0.05)$.

Duck strain affected composition of fatty acids in thighs. STAR 53 hybrid duck thighs had higher contents of elaidic (C18:1n9t), trans vaccenic (C18:1n11t), and trans octadecadienoic acid (C18:2n6) than did thighs of SM3 hybrids $(P<0.01)$. Percentages of pentadecanoic (C15:0), eicosenoic (C20:1n9), linoleic acid 
(C18:2n6c), and alpha-linolenic acid (C18:3 n-3), and the PUFA to SFA ratio were higher $(P<0.05)$ in thighs of SM3 ducks than in STAR 53 ducks. Regarding housing conditions, in ducks reared in the intensive housing system, percentages of heptadecanoic (C17:0) and trans vaccenic acid (C18:1n11t), the total n-3 PUFA content, PUFA to SFA ratio, and $\mathrm{H} / \mathrm{H}$ ratio were higher than in semi-intensively reared ducks $(P<0.05)$. The contents of palmitic (C16:0) and palmitoleic (C16:1) acids, ratio of n-6 to n-3 PUFA, and Al were higher $(P<0.05)$ in ducks housed in the semi-intensive system than in those reared intensively. Significant interactions were found between duck strain and housing system on elaidic acid content (C18:1n9t) and PUFA to SFA ratio $(P<0.05)$.

In Table 6 presents the differences between breasts and thighs within the four experimental groups in the sum of the major classes of fatty acids, MUFA to SFA ratio, PUFA to SFA ratio, UFA to SFA ratio, $n-6$ to $n-3$ PUFA ratio, $\mathrm{Al}, \mathrm{TI}$, and $\mathrm{H} / \mathrm{H}$ ratio. Higher contents of total SFA of intensively reared SM3 ducks and n-3 PUFA of semi-intensively housed STAR 53 ducks were measured in breasts than in thighs $(P<0.01)$. In all experimental groups, the MUFA to SFA and UFA to SFA ratios were lower in breasts than in thighs $(P<0.01)$. In breasts of ducks reared in the housing system with open access to the outdoors, PUFA to SFA ratios were higher than in thighs $(P<0.01)$. Als were higher $(P<0.01)$ in breasts of intensively reared ducks than in thighs $(P<0.01)$. Furthermore, Tls were higher in breasts of all experimental groups than in thighs $(P<0.05)$, except for STAR 53 ducks reared in the intensive system. In breasts of all experimental groups, lower $\mathrm{H} / \mathrm{H}$ ratios were determined than in thighs $(P<0.01)$.

\section{Discussion}

\section{Chemical characteristics of meat}

In our study, chemical analysis of meat showed that STAR 53 ducks had higher moisture and lower protein contents in breasts than did SM3 hybrid ducks. The compared strains of Pekin duck did not differ in chemical composition of thighs. Other authors investigated chemical composition of different strains of

Pekin ducks and found that genetics influenced the contents of moisture, protein, lipid and collagen in breasts and thighs $[10,33,34,35]$. Moreover, in our study, housing system did not affect the chemical composition of duck meat, as also was confirmed by Michalczuk et al. [36] for Pekin duck and Michalczuk et al. [37] for Muscovy duck. On the contrary, Bai et al. [38] found higher fat content in ducks reared in cages than in those reared on net, and that in the group with a medium stocking density, contents of moisture, fat, and collagen were higher than in groups with high or low stocking density. Similarly, Abo Ghanima et al. [39] showed that meat of Pekin ducks reared in a housing system with swimming pool and yard had lower triacylglycerol and cholesterol contents than those reared in housing systems without combined swimming pool and yard. This reduction in fat content may be attributed to the increased physical activity in ducks that had access to the yard and swimming pool [39]. Since in our study chemical composition of meat did not differ between two housing systems, it seems the two rearing systems induced similar levels of physical activity in the ducks.

\section{Fatty acid profile of meat}


Fatty acid composition of meat affects meat quality and nutritional value of meat [4]. In our study, the fatty acid composition of breasts and thighs was dominated by MUFA, followed by PUFA and SFA. Similarly, other authors found that MUFA were the most abundant fatty acids in duck meat $[4,6,11,40]$. However, the highest PUFA content was determined by Aronal et al. [8], while other authors showed that SFA were the predominant fatty acids in duck meat $[10,41,42]$. The differences between our study and the previously cited ones in fatty acid composition of duck meat may be a result of different genetics, sex, age, diet, and rearing conditions [4]. Diet is one of the most important factors influencing fatty acid composition of meat [43]. In the current study, the predominant fatty acids in diets were PUFA (approximately $50 \%$ of total fatty acids), due to the high linoleic acid contents (C18:2n6). Opposite to that, breasts and thighs of our ducks contained the highest proportion of oleic acid (C18:1n9c), followed by linoleic (C18:2n6c), palmitic (C16:0), and stearic (C18:0) acids. The most abundant fatty acids accounted for approximately $88 \%$ of total fatty acids in both types of meat. These results were in agreement with those reported by Fan et al. [4] and Onk et al. [11]. Higher contents of MUFA determined in our study and the study of Onk et al. [11] than were reported by Banaszak et al. [41] could be a consequence of diet based mainly on maize (approximately $60 \%$ ), as Onk et al. [11] have concluded. Overfeeding ducks with maize-based diet induces lipogenesis in liver and accumulation of MUFA-rich triglycerides in muscles [44]. Thus, it seems that PUFA from our ducks' diets were converted during duck metabolism into other fatty acids, mostly MUFA. Moreover, Fan et al. [4] found that Pekin ducks have large capacities to accumulate MUFA (mainly palmitoleic and oleic acids) and SFA (mainly palmitic acid) as storage fats, due to their high adipogenic potential. These fatty acids are mainly products of de novo fatty acid biosynthesis [4]. Furthermore, the content of SFA and PUFA, the PUFA to SFA ratio, $\mathrm{n}-6$ to $\mathrm{n}-3$ PUFA ratio, $\mathrm{Al}, \mathrm{Tl}$, and $\mathrm{H} / \mathrm{H}$ ratio are commonly used as indicators of nutritional value of meat $[30,31]$. With regard to human health, a ratio of $n-6$ to $n-3$ PUFA that is lower than 4 [3] and a ratio of total PUFA to total SFA that is higher than 0.4 [32] are recommended. In our study, the recommended PUFA to SFA ratio was achieved in breasts and thighs of all experimental groups (from 0.91 to 1.07). However, in the current study, the ratio of n-6 to n-3 PUFA was several times greater than recommended (it was from 19.70 to 20.71 ) and determined in other studies $[7,8,10,11,41]$. This imbalance in the $n-6$ to $n-3$ PUFA ratio determined in our study was a consequence of diet, based mainly on maize and soybean that contained high levels of linoleic acid ( $n-6$ fatty acid), and insufficient quantities of feeds that were sources of n-3 fatty acids. The importance of a balanced n-6 to n-3 fatty acid ratio is based on the fact that consumption of high rates of $n-6$ fatty acids has been linked with a higher occurrence of health problems, such as type 2 diabetes, obesity, and coronary artery diseases. On the other hand, n-3 fatty acids have shown many health benefits, since they are important in fetal development, reduce risk of developing cardiovascular diseases, prevent Alzheimer's disease, and have anti-inflammatory properties [3].

In our study, duck strain mainly had no significant effect on the fatty acid profile in breasts, but significantly affected fatty acid composition in thighs. Thighs of SM3 ducks contained higher contents of desirable fatty acids (linoleic and alpha-linolenic acid) and lower percentages of trans fatty acids (total of trans octadecadienoic acid isomers) that are associated with cardiovascular disease, cancer, or diabetes [45] than did thighs of STAR 53 ducks. Therefore, higher a PUFA to SFA ratio was determined in thighs of SM3 ducks than in STAR 53 ducks, indicating the more favorable chemical composition of SM3 duck meat. Other authors have found significant differences in fatty acid composition of meat of different duck 
genotypes: Pekin vs. Muscovy duck [8], Korean native duck vs. Pekin duck [9], Cherry Valley vs. Spent Layer vs. Crossbred duck [10], Pekin vs. Native duck [11] and Pekin vs. Mallard [4]. Most of the studies showed the meat of Pekin duck had lower nutritional value due to lower proportions of total n-3 PUFA content, total n- 6 PUFA content, lower PUFA to SFA ratio, and higher Al or TI than meat of Native duck [11], Korean native duck [9] and Mallard [4]. Genetics does influence the fatty acid composition of duck meat, as shown by these previous studies, and in the current study, differences in fatty acid profile could be ascribed to genetic variations between our two strains of Pekin duck.

Rearing conditions affected fatty acid composition of thighs, and a more favorable fatty acid profile was determined in intensively reared ducks than in ducks reared in the semi-intensive housing system. Thighs of ducks reared in the semi-intensive system were characterized by a higher n-6 to n-3 PUFA ratio, lower PUFA to SFA ratio and $\mathrm{H} / \mathrm{H}$ ratio, and higher $\mathrm{Al}$ than ducks reared in the intensive system. Regarding the different fatty acid profiles of intensively and semi-intensively reared ducks, it could be assumed that ducks reared in the housing system with open access to land had prolonged exposure to lower ambient temperatures, which could have led to greater oxidative metabolism in skeletal muscles and higher deposition of SFA as intramuscular storage fats [46]. Although we did not find significant differences in SFA contents of thighs between the two housing groups, the SFA contents in thighs of semi-intensively reared ducks were higher than in ducks from the intensive system, which probably contributed to lower nutritional value of meat.

Comparing fatty acid composition of breasts and thighs we found better meat quality of thighs than breasts, expressed through lower content of SFA in one experimental group, and higher MUFA to SFA ratio, and UFA to SFA ratio of all our experimental groups than in breasts. Better meat quality of thighs than breasts was also determined in other studies [8, 10], while Suci et al. [40] found the opposite. Moreover, thighs had lower $\mathrm{Al}$ in intensively reared ducks, lower $\mathrm{Tl}$ in three experimental groups, and higher $\mathrm{H} / \mathrm{H}$ ratio in all experimental groups of ducks than in breasts. Fatty acid profile predominantly depends on animal species, muscle type, anatomical location of muscle, and content, composition, and quality of dietary fats in feed [1]. Differences between breasts and thighs with regard to fatty acid composition of all our experimental groups could be ascribed to different tendencies of examined muscles (M. pectoralis superficialis vs. M. iliotibialis) to store different fatty acids into membrane phospholipids [1].

\section{Lipid and protein oxidation of meat}

The extent of lipid oxidation in fresh breasts and thighs of our ducks ranged from 0.47 to $1.08 \mathrm{mg}$ of MDA per $\mathrm{kg}$ of meat. Other authors found lower TBARS values in duck meat than we did [6, 47]. The high TBARS values determined in our study could be a consequence of very high content of n-6 PUFA, low content of n-3 PUFA, high n-6 to n-3 ratio, and high PUFA to SFA ratio, since PUFA provide the substrate for the formation of lipid oxidation products [7]. A moderate intake of n-3 PUFA enhances anti-oxidative properties of tissues through inducing higher activity of glutathione peroxidase, glutathione $S$ transferase, and superoxide dismutase, and consequently, decreases the extent of lipid peroxidation [3]. Moreover, reducing the ratio of n-6 to n-3 PUFA was found to be linked to lower content of lipid oxidation products, since n-3 PUFA, due to their higher number of bis-allylic positions, protect n-6 PUFA from oxidation [7]. After storage of frozen meat for 6 weeks, TBARS values increased (from 0.96 to $1.24 \mathrm{mg}$ of MDA/kg sample). Similarly, other authors 
observed higher TBARS values with increasing storage time $[6,47]$. Oxygen availability is one of the most important factors for the development of the lipid peroxidation in meat during storage [1].

In our study, duck strain did not affect lipid oxidation, except in frozen thighs, where higher TBARS values were determined in SM3 hybrid ducks than in STAR 53 ducks. Those differences could be explained by the different fatty acid profiles of thighs of the two hybrids. SM3 hybrid Pekin ducks contained a higher level of linoleic acid (n-6) than STAR 53 ducks, producing favorable conditions for lipid peroxidation. Moreover, rearing conditions affected TBARS values in fresh thighs and frozen breasts and thighs. In intensively reared ducks, TBARS values were higher than in ducks that had access to land. In breasts and thighs of intensively reared ducks, higher percentages of total n-6 PUFA and higher PUFA to SFA ratios were found than in ducks from the semi-intensive housing system. Similarly, differences in MDA content between fresh samples of breasts and thighs depended on fatty acid composition of the meat. Higher TBARS values in breasts than in thighs resulted from their higher n-6 PUFA content and higher PUFA to SFA ratio. Although those differences were not significant in all compared groups, apparently they contributed to different extent of lipid oxidation. On the contrary, Van Hecke et al. [7] concluded the n-6 to n-3 ratio correlated more with PUFA oxidation than did the absolute content of PUFA, which was not confirmed in our study. Moreover, rearing conditions affect animal welfare and, consequently, the level of preslaughter stress and meat quality [13]. Preslaughter stress induces glycogenolysis and $\mathrm{pH}$ decline. After slaughter, the in vivo antioxidant mechanisms partially collapse, while postmortal biochemical changes, such as increasing the level of $\mathrm{H}^{+}$, favor oxidation of both lipids and proteins [5]. Our results, where higher TBARS values were determined in ducks reared in the intensive system than in ducks from housing system that had open access to land, accorded with this. Similarly, Abo Ghanima et al. [39] found that housing system with an open yard provided lower MDA levels than housing systems without yards. Moreover, Zhu et al. [48] found that higher preslaughter stress induced higher TBARS values in ducks.

In our study, protein carbonyl content ranged from 3.10 to $6.70 \mathrm{nmol} / \mathrm{mg}$ of protein and was in accordance with results of other authors $[7,48]$. Protein carbonyl content measured in breasts and thighs of our ducks correlated with products of lipid peroxidation, since they contribute to protein carbonylation [5]. Therefore, protein carbonyl values were higher in fresh breasts and thighs of intensively reared ducks than in ducks reared in semi-intensive housing system. Furthermore, the protein carbonyl content was higher in breasts than in thighs, as was also observed with TBARS values. In our study, frozen duck meat had higher protein carbonyl contents than fresh duck meat, since meat proteins undergo carbonylation during frozen storage, and significant increase was found in the first two months of storage at $-18{ }^{\circ} \mathrm{C}$ [5].

\section{Conclusions}

In conclusion, this study revealed that duck strain affects the fatty acid profile of duck meat. SM3 ducks had more favorable fatty acid composition of thigh meat than STAR 53 ducks and those differences could be ascribed to genetic variations. Furthermore, we found the housing system influenced the nutritional value of meat. Although intensively reared ducks had a more desirable fatty acid profile of meat than ducks from the semi-intensive housing system, they were more prone to lipid and protein oxidation than ducks that had open access to land. We concluded that total n-6 PUFA content and PUFA to SFA ratio were linked 
with both lipid and protein oxidation products, since the main substrate for oxidation processes is PUFA. In addition, the higher level of lipid and protein oxidation products in intensively reared birds could indicate those ducks were exposed to higher preslaughter stress and increased postmortal biochemical processes than ducks from the semi-intensive housing system.

\section{Abbreviations}

Al: atherogenicity index; BHT: butylated hydroxytoluene; DNP: 2,4-dinitrophenyl; DNPH: 2,4dinitrophenylhydrazine; FAMEs: fatty acid methyl esters; $\mathrm{H} / \mathrm{H}$ : hypocholesterolemic to hypercholesterolemic fatty acids ratio; MDA: malondialdehyde; MUFA: monounsaturated fatty acids; PCC: protein carbonyl compounds; PUFA: polyunsaturated fatty acids; SFA: saturated fatty acids; TBA: 2-Thiobarbituric acid; TBARS: 2-thiobarbituric acid reactive substances; TCA: trichloroacetic acid; TI: thrombogenicity index; UFA: unsaturated fatty acids.

\section{Declarations}

\section{Acknowledgements}

Not applicable.

\section{Authors' contributions}

MŽB and RM designed the experiment. HM and BB performed the experiment. MS analyzed the study data and prepared the manuscript. MP and RM gave advice on the experiment design. The manuscript was edited by NG, JJ and MG. All authors read and approved the final manuscript.

\section{Funding}

The study was supported by the Ministry of Education, Science and Technological Development of the Republic of Serbia (Contract number 451-03-68/2020-14/200143).

\section{Availability of data and materials}

All data generated or analyzed during this study are included in this published article.

\section{Ethics approval and consent to participate}

Before the start of the study, the experimental protocol was approved by the Veterinary Directorate of the Serbian Ministry of Agriculture, Forestry and Water Management and the Ethics Committee of the Faculty of Veterinary Medicine, University of Belgrade.

\section{Consent for publication}

Not applicable. 


\section{Competing interests}

The authors declare no competing interests.

\section{Author details}

${ }^{1}$ Department for Food Hygiene and Technology, Faculty of Veterinary Medicine, University of Belgrade, Bulevar Oslobodjenja 18, Belgrade 11000, Serbia. ${ }^{2}$ Department of Food Technology, Faculty of Technology, University of Tuzla, Univerzitetska 8, 75000 Tuzla, Bosnia and Herzegovina. ${ }^{3}$ Institute of Meat Hygiene and Technology, Kaćanskog 13, Belgrade 11000, Serbia. ${ }^{4}$ Department for Hygiene, Faculty of Medicine, University of Novi Sad, Hajduk Veljkova 3, 21137 Novi Sad, Serbia.

\section{References}

1. Min B, Ahn DU. Mechanism of Lipid Peroxidation in Meat and Meat Products - A Review. Food Sci Biotechnol. 2005;14:152 - 163.

2. Dominguez R, Pateiro M, Gagaoua M, Barba FJ, Zhang W, Lorenzo JM. A comprehensive review on lipid oxidation in meat and meat products. Antioxidants. 2019; doi:10.3390/antiox810042.

3. Alagawany M, Elnesr SS, Farag MR, Abd El-Hack ME, Khafaga AF, Taha AE, et al. Omega-3 and omega6 fatty acids in poultry nutrition: effect on production performance and health. Animals. 2019; doi:10.3390/ani9080573.

4. Fan W, Liu W, Liu H, Meng Q, Xu Y, Guo Y, et al. Dynamic accumulation of fatty acids in duck (Anas platyrhynchos) breast muscle and its correlations with gene expression. BMC Genomics, 2020; doi: https://doi.org/10.1186/s12864-020-6482-7.

5. Estevez M. Protein carbonyls in meat systems: A review. Meat Sci. 2011;89:259-279.

6. Ali MS, Kang GH, Yang HS, Jeong JY, Hwang YH, Park GB, et al. A Comparison of meat characteristics between duck and chicken breast. Asian-Australas J Anim. 2007; 20:1002 - 1006.

7. Van Hecke T, Goethals S, Vossen E, De Smet S. Long-chain n-3 PUFA content and n-6/n-3 PUFA ratio in mammal, poultry, and fish muscles largely explain differential protein and lipid oxidation profiles following in vitro gastrointestinal digestion. Mol Nutr Food Res. 2019;doi: 10.1002/mnfr.201900404.

8. Aronal AP, Huda N, Ahmad R. Amino acid and fatty acid profiles of Peking and Muscovy duck meat. Int J Poult Sci. 2012;11:229-236.

9. Muhlisin M, Kim DS, Song YR, Kim HR, Kwon HJ, An BK, et al. Comparison of meat characteristics between Korean native duck and imported commercial duck raised under identical rearing and feeding condition. Korean J Food Sci Anim Resour. 2013;1:89-95.

10. Qiao Y, Huang J, Chen Y, Chen H, Zhao L, Huang M, et al. Meat quality, fatty acid composition and sensory evaluation of Cherry Valley, Spent Layer and Crossbred ducks, Anim Sci J.2017;88:156-165.

11. Onk K, Yalcintan H, Sari M, Isik SA, Yakan A, Ekiz B.. Effects of genotype and sex on technological properties and fatty acid composition of duck meat. Poultry Sci. 2019;98:491-499. 
12. Faure JM, Val-Laillet D, Guy G, Bernadet MD, Guemene D. Fear and stress reactions in two species of duck and their hybrid. Horm Behav. 2003;43:568-572.

13. Onbasilar EE, Yalcin S. Fattening performance and meat quality of Pekin ducks under different rearing systems. Worlds Poult Sci J. 2018;74:61-68.

14. National Research Council (NRC) Nutrient requirements of poultry. 9th rev. ed. Washington, DC: National Academy Press; 1994.

15. International Organization for Standardization (ISO). ISO 6496. Animal feeding stuffs. Determination of moisture and other volatile matter content. ISO, Geneva, Switzerland; 1999.

16. International Organization for Standardization (ISO). ISO 5983-1. Animal feeding stuffs. Determination of nitrogen content and calculation of crude protein content: Kjeldahl method. ISO, Geneva, Switzerland; 2005.

17. International Organization for Standardization (ISO). ISO 6492. Animal feeding stuffs. Determination of fat content. ISO, Geneva, Switzerland; 1999.

18. International Organization for Standardization (ISO). ISO 6865. Animal feeding stuffs. Determination of crude fibre content: method with intermediate filtration. ISO, Geneva, Switzerland; 2000.

19. International Organization for Standardization (ISO). ISO 6490-1. Animal feeding stuffs. Determination of calcium content: titrimetric method. ISO, Geneva, Switzerland; 1985.

20. International Organization for Standardization (ISO). ISO 6491. Animal feeding stuffs. Determination of phosphorus content: Spectrometric method. ISO, Geneva, Switzerland; 1998.

21. Sinovec Z, Ševković N. Practicum for animal nutrition. Belgrade: Faculty of Veterinary Medicine, University of Belgrade; 1995.

22. International Organization for Standardization (ISO). ISO 1442. Meat and meat products. Determination of moisture content (Reference method). ISO, Geneva, Switzerland; 1997.

23. International Organization for Standardization (ISO). ISO 1443. Meat and meat products. Determination of total fat content. ISO, Geneva, Switzerland; 1973.

24. International Organization for Standardization (ISO). ISO 937. Meat and meat products. Determination of nitrogen content (Reference method). ISO, Geneva, Switzerland; 1978.

25. International Organization for Standardization (ISO). ISO 3496. Meat and meat products. Determination of hydroxyproline content. ISO, Geneva, Switzerland; 1994.

26. Spirić A, Trbović D, Vranić D, Đinović J, Petronijević R, Matekalo-Sverak V. Statistical evaluation of fatty acid profile and cholesterol content in fish (common carp) lipids obtained by different sample preparation procedures. Anal Chim Acta. 2010;672:66-71.

27. International Organization for Standardization (ISO). ISO 5509. Animal and Vegetable Fats and Oils Preparation of Methyl Esters of Fatty Acids. ISO, Geneva, Switzerland; 2000.

28. Botsoglou NA, Fletouris DJ, Papageorgiou GE, Vassilopoulos VN, Mantis AJ, Trakatellis A. Rapid, sensitive, and specific thiobarbituric acid method for measuring lipid peroxidation in animal tissue, food, and feedstuff samples. J Agric Food Chem. 1994;42:1931-1937. 
29. Dalle-Donne I, Rossi R, Giustarini D, Milzani A, Colombo R. Protein carbonyl groups as biomarkers of oxidative stress. Clin Chim Acta. 2003;329:23-38.

30. Ulbricht TLV, Southgate DAT. Coronary heart disease: Seven dietary factors. Lancet 1991;338:985-992.

31. Paszczyk B, Polak-Sliwinska M, Luczynska J. Fatty Acids Profile, Trans Isomers, and Lipid Quality Indices in Smoked and Unsmoked Cheeses and Cheese-Like Products. Int J Environ Res Public Health 2020; doi:10.3390/ijerph17010071.

32. Wood JD, Enser M, Fisher AV, Nute GR, Sheard PR, Richardson RI, et al. Fat deposition, fatty acid composition and meat quality: A review. Meat Sci. 2008;78:343-358.

33. Kokoszynski D, Arpasova H, Hrncar C, Zochowska-Kujawska J, Kotowicz M, Sobczak M. Carcass characteristics, chemical composition, physicochemical properties, texture, and microstructure of meat from spent Pekin ducks. Poultry Sci. 2019; 99:1232-1240.

34. Kokoszynski D, Wasilewski R, Steczny K, Kotowicz M, Hrncar C, Arpasova H. Carcass composition and selected meat quality traits of Pekin ducks from genetic resources flocks. Poultry Sci. 2019;98:30293039.

35. Kokoszynski D, Piwczynski D, Arpasova H, Hrncar C, Saleh M, Wasilewski R. A comparative study of carcass characteristics and meat quality in genetic resources Pekin ducks and commercial crossbreds. Asian-Australas J Anim Sci. 2019;32:1753-1762.

36. Michalczuk M, Damaziak K, Pietrzak D, Marzec A, Chmiel M, Adamczak L, et al.. Influence of housing system on selected quality characteristics of duck meat. Chapter 1. Pekin duck. Annals of Warsaw University of Life Sciences-SGGW Animal Science. 2016; 55:89-97.

37. Michalczuk M, Damaziak K, Pietrzak D, Marzec A, Chmiel M, Adamczak L, et al. Influence of housing system on selected quality characteristics of duck meat. Chapter 2. Muscovy duck. Annals of Warsaw University of Life Sciences-SGGW Animal Science. 2017;56:277-285.

38. Bai H, Bao Q, Zhang Y, Song Q, Liu B, Zhong L, et al. Research Note: Effects of the rearing method and stocking density on carcass traits and proximate composition of meat in small-sized meat ducks. Poult Sci. 2020;99:2011-2016.

39. Abo Ghanima MM, El-Edel M A, Ashour E A, Abd El-Hack ME, Othman SI, Alwaili MA, et al. The influences of various housing systems on growth, carcass traits, meat quality, immunity and oxidative stress of meat-type ducks. Animals. 2020; doi:10.3390/ani10030410.

40. Suci DM, Fitria Z, Mutia R. Meat fatty acid and cholesterol content of native Indonesian Muscovy duck fed with rice bran in traditional farm. Anim prod. 2017;19:37-45.

41. Banaszak M, Kuźniacka J, Biesek J, Maiorano G, Adamski M. Meat quality traits and fatty acid composition of breast muscles from ducks fed with yellow lupin. Animal. 2020; doi:10.1017/S1751731120000610.

42. Kwon HJ, Choo YK, Choi YI, Kim EJ, Kim HK, Heo KN et al. Carcass characteristics and meat quality of Korean native ducks and commercial meat-type ducks raised under same feeding and rearing conditions. Asian-Australas J Anim Sci. 2014; 27:1638-1643. 
43. MacRae J, O'Reilly L, Morgan P. Desirable characteristics of animal products from a human health perspective. Livest Prod Sci. 2005; 94:95-103.

44. Chartrin P, Meteau K, Juin H, Bernadet MD, Guy G, Larzul C, Remignon H, Mourot J, Duclos MJ, Baeza E. Effects of intramuscular fat levels on sensory characteristics of duck breast meat. Poult Sci. 2006; 5:914-922.

45. Islam MA, Amin MN, Siddiqui SA, Hossain P, Sultana F, Kabir R. Trans fatty acids and lipid profile: A serious risk factor to cardiovascular disease, cancer and diabetes. Diabetes Metab Syndr. 2019;13:1643-1647.

46. Hocquette JF, Ortigues-Marty I, Pethick D, Herpin P, Fernandez X. Nutritional and hormonal regulation of energy metabolism in skeletal muscles of meat-producing animals. Livest Prod Sci. 1998;56:115-143.

47. Park JH, Kang SN, Shin D, Shim KS. Antioxidant enzyme activity and meat quality of meat type ducks fed with dried oregano (Origanum vulgare) powder, Asian-Australas J Anim Sci. 2015;28:79-85.

48. Zhu Z, Chen Y, Huang Z, Zhang Y, Xu Q, Tong Y, et al. Effects of transport stress and rest before slaughter on blood parameters and meat quality of ducks. Can J Anim Sci. 2014;94:595-600.

\section{Tables}

Table 1 Ingredients and chemical composition of diets 


\begin{tabular}{|llll|}
\hline Ingredient (g/kg as-fed) & Starter & Grower & Finisher \\
& $(1-21$ days $)$ & $(22-35$ days $)$ & $(36-49$ days $)$ \\
\hline Maize & 606 & 608.3 & 633.3 \\
\hline Soybean meal 46\% & 310 & 180 & 170 \\
\hline Sunflower meal & 30 & 60 & 50 \\
\hline Yeast & 20 & 30 & 20 \\
\hline Mono-calcium phosphate & 21.5 & 20 & 20 \\
\hline Wheat feed flour & - & 50 & 35 \\
\hline Full-fat soybean meal & - & 40 & 60 \\
\hline Vitamin-mineral premix & 10.0 & 10.0 & 10.0 \\
\hline DL-methionine & 1.2 & 0.8 & 0.8 \\
\hline L-lysine & 1.3 & 0.9 & 0.9 \\
\hline Chemical composition $(\mathrm{g} / \mathrm{kg}$ as-fed) & & \\
\hline Dry matter & 895.00 & 886.00 & 882.00 \\
\hline Crude protein & 214.10 & 196.00 & 190.00 \\
\hline Crude fat & 25.00 & 43.00 & 37.00 \\
\hline Crude fiber & 39.00 & 47.00 & 46.00 \\
\hline Calcium & 11.70 & 10.10 & 9.60 \\
\hline Phosphorus & 4.90 & 5.20 & 4.50 \\
\hline Calculated composition (g/kg as-fed) & & 9.90 \\
\hline Lysine & 13.50 & 11.70 & 7.10 \\
\hline Methionine & 5.70 & 5.60 & 8.50 \\
\hline Methionine + cysteine & 9.00 & & \\
\hline
\end{tabular}

aVitamin-mineral premix (per kg of diet): vitamin A (retinyl acetate), $10000 \mathrm{IU}$; vitamin D3 (cholecalciferol), 4000 IU; vitamin E (a-tocopherol), 20 mg; vitamin K3 (menadione), 3 mg; vitamin B1 (thiamine), $2.2 \mathrm{mg}$; vitamin B2 (riboflavin), 8 mg; vitamin B3 (niacin), 65 mg; vitamin B5 (calcium pantotenate), $25 \mathrm{mg}$; vitamin B6 (pyridoxine), $5 \mathrm{mg}$; vitamin B7 (biotin), $0.3 \mathrm{mg}$; vitamin B9 (folic acid), $1.5 \mathrm{mg}$; vitamin B12 (cyanocobalamin), 0.02 mg; iron (FeSO4), 80 mg; copper (CuSO4), 8 mg; manganese (MnSO4), 60 mg; zinc (ZnSO4), $40 \mathrm{mg}$; iodine (KI), $0.33 \mathrm{mg}$.

Table 2 Fatty acid composition (\% of total fatty acids) of diets 


\begin{tabular}{|llll|}
\hline Fatty acids & Starter & Grower & Finisher \\
& $(1-21$ days) & $(22-35$ days $)$ & $(36-49$ days) \\
\hline Lauric acid (C12:0) & 0.02 & 0.02 & 0.02 \\
\hline Myristic acid (C14:0) & 0.11 & 0.1 & 0.08 \\
\hline Pentadecanoic acid (C15:0) & 0.04 & 0.04 & 0.03 \\
\hline Palmitic acid (C16:0) & 17.31 & 15.74 & 14.82 \\
\hline Heptadecanoic acid (C17:0) & 0.09 & 0.09 & 0.09 \\
\hline Stearic acid (C18:0) & 2.93 & 3.59 & 3.99 \\
\hline Arachidic acid (C20:0) & 0.38 & 0.37 & 0.42 \\
\hline Behenic acid (C22:0) & 0.19 & 0.21 & 0.23 \\
\hline Lignoceric acid (C24:0) & 0.2 & 0.14 & 0.18 \\
\hline$\sum$ SFA & 21.27 & 20.30 & 19.86 \\
\hline Palmitoleic acid (C16:1) & 0.08 & 0.09 & 0.08 \\
\hline Elaidic acid (C18:1n9t) & 0.5 & 0.43 & 0.46 \\
\hline Oleic acid (C18:1n9c) & 22.47 & 24.27 & 23.36 \\
\hline trans Vaccenic acid (C18:1n11t) & 0.81 & 0.87 & 0.89 \\
\hline cis Vaccenic acid (C18:1n11c) & 2.8 & 3.01 & 2.78 \\
\hline Eicosenoic acid (C20:1n9) & 0.21 & 0.23 & 0.18 \\
\hline$\sum$ MUFA & 26.87 & 28.9 & 27.75 \\
\hline Linoleic acid (C18:2n6) & 42.84 & 42.33 & 43.29 \\
\hline total trans Octadecadienoic acid (C18:2n6) & 7.48 & 6.89 & 7.19 \\
\hline$\sum n-6$ PUFA & 50.33 & 49.22 & 50.48 \\
\hline Alpha-linolenic acid (C18:3n3) & 1.52 & 1.61 & 1.9 \\
\hline$\sum n-6$ PUFA/ $\sum n-3$ PUFA & 33.11 & 30.57 & 26.57 \\
\hline
\end{tabular}

Table 3 The effect of Pekin duck strain and housing system on chemical characteristics, TBARS and protein carbonyl values of meat 


\begin{tabular}{|c|c|c|c|c|c|c|c|c|c|c|}
\hline \multirow[t]{3}{*}{ Parameter } & \multirow[t]{3}{*}{ Tissue } & \multirow[b]{3}{*}{$n$} & \multicolumn{8}{|c|}{ Duck strain (S) - Housing system $(\mathrm{H})$} \\
\hline & & & \multicolumn{2}{|l|}{ STAR 53} & \multicolumn{2}{|l|}{ SM3 } & \multirow[t]{2}{*}{ SEM } & \multicolumn{3}{|c|}{$P$ value } \\
\hline & & & $\begin{array}{l}\text { Intensive } \\
\text { system }\end{array}$ & $\begin{array}{l}\text { Semi- } \\
\text { intensive } \\
\text { system }\end{array}$ & $\begin{array}{l}\text { Intensive } \\
\text { system }\end{array}$ & $\begin{array}{l}\text { Semi- } \\
\text { intensive } \\
\text { system }\end{array}$ & & S & $\mathrm{H}$ & $\mathrm{SxH}$ \\
\hline \multirow{2}{*}{$\begin{array}{l}\text { Moisture } \\
(\%)\end{array}$} & Breast & 6 & $74.61^{\mathrm{ab}}$ & $74.81^{\mathrm{a}}$ & $73.86^{\mathrm{b}}$ & $74.43^{\mathrm{ab}}$ & 0.47 & * & ns & ns \\
\hline & Thigh & 6 & 73.72 & 73.91 & 73.72 & 73.88 & 0.65 & ns & ns & ns \\
\hline \multirow{2}{*}{$\begin{array}{l}\text { Protein } \\
(\%)\end{array}$} & Breast & 6 & $22.22^{\mathrm{abX}}$ & $21.97^{\mathrm{ax}}$ & $23.01^{\mathrm{bX}}$ & $22.50^{\mathrm{abX}}$ & 0.50 & * & ns & ns \\
\hline & Thigh & 6 & $20.04^{Y}$ & $19.91^{Y}$ & $20.21^{Y}$ & $19.51^{Y}$ & 0.40 & ns & ns & ns \\
\hline \multirow[t]{2}{*}{ Lipid (\%) } & Breast & 6 & $2.17^{x}$ & $2.22^{x}$ & $2.14^{x}$ & $2.07^{x}$ & 0.26 & ns & ns & ns \\
\hline & Thigh & 6 & $5.11^{Y}$ & $5.02^{Y}$ & $4.93^{Y}$ & $5.48^{\mathrm{Y}}$ & 0.72 & ns & ns & ns \\
\hline \multirow{2}{*}{$\begin{array}{l}\text { Collagen } \\
(\%)\end{array}$} & Breast & 6 & 1.60 & 1.39 & 1.29 & 1.38 & 0.19 & ns & ns & ns \\
\hline & Thigh & 6 & 1.34 & 1.24 & 1.22 & 1.29 & 0.12 & ns & ns & ns \\
\hline \multirow{2}{*}{$\begin{array}{l}\text { TBARS in } \\
\text { fresh } \\
\text { sample } \\
\text { (mg } \\
\mathrm{MDA} / \mathrm{kg})\end{array}$} & Breast & 10 & $0.94^{X}$ & $1.08^{\mathrm{X}}$ & $0.92^{\mathrm{X}}$ & $0.95^{x}$ & 0.10 & ns & ns & ns \\
\hline & Thigh & 10 & $0.57^{\mathrm{abY}}$ & $0.47^{\mathrm{aY}}$ & $0.61^{\mathrm{bY}}$ & $0.47^{\mathrm{aY}}$ & 0.06 & ns & 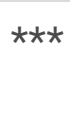 & ns \\
\hline \multirow{2}{*}{$\begin{array}{l}\text { TBARS in } \\
\text { frozen } \\
\text { sample } \\
\text { (mg } \\
\mathrm{MDA} / \mathrm{kg})\end{array}$} & Breast & 10 & 1.24 & 1.10 & 1.31 & 1.10 & 0.11 & ns & ** & ns \\
\hline & Thigh & 10 & $0.96^{\mathrm{AB}}$ & $0.82^{\mathrm{A}}$ & $1.12^{\mathrm{B}}$ & $0.97^{A B}$ & 0.10 & $\star \star$ & $\star \star$ & ns \\
\hline \multirow{2}{*}{$\begin{array}{l}\text { Protein } \\
\text { carbonyls } \\
\text { in fresh } \\
\text { sample } \\
\text { (nmol/mg } \\
\text { of } \\
\text { protein) }\end{array}$} & Breast & 10 & 5.71 & 4.35 & 6.45 & $5.41^{x}$ & 1.17 & ns & * & ns \\
\hline & Thigh & 10 & $4.68^{\mathrm{A}}$ & $3.30^{\mathrm{B}}$ & $5.52^{\mathrm{A}}$ & $3.10^{\mathrm{By}}$ & 0.74 & ns & $\star \star \star$ & ns \\
\hline \multirow{2}{*}{$\begin{array}{l}\text { Protein } \\
\text { carbonyls } \\
\text { in frozen } \\
\text { sample } \\
\text { (nmol/mg } \\
\text { of } \\
\text { protein) }\end{array}$} & Breast & 10 & 5.53 & 6.70 & 4.53 & 6.44 & 1.52 & ns & ns & ns \\
\hline & Thigh & 10 & 5.02 & 6.48 & 5.53 & 6.22 & 1.82 & ns & ns & ns \\
\hline
\end{tabular}

Data are means and standard error of means (SEM). Within a row, means with a different superscript letter differ $(a, b-P<0.05 ; A, B-P<0.01)$; Within a column of each parameter, means with a different superscript 
letter differ $(\mathrm{X}, \mathrm{y}-P<0.05 ; \mathrm{X}, \mathrm{Y}-P<0.01)$.

STAR 53 = STAR 53 medium hybrid of Pekin duck; SM3 = SM3 heavy hybrid of Pekin duck; $\mathrm{S}=$ duck strain factor; $\mathrm{H}=$ housing factor; $\mathrm{SxH}=$ interaction between duck strain and housing factor; $\mathrm{ns}=$ no significance $(P>0.05) ; * P<0.05 ; * \star P<0.01 ; * \star \star P<0.001$.

Table 4 The effect of Pekin duck strain and housing system on fatty acid profile of breasts $(n=6)$ 


\begin{tabular}{|c|c|c|c|c|c|c|c|c|}
\hline \multirow[t]{3}{*}{ Fatty acid } & \multicolumn{8}{|c|}{ Duck strain $(\mathrm{S})$ - Housing system $(\mathrm{H})$} \\
\hline & \multicolumn{2}{|l|}{ STAR 53} & \multicolumn{2}{|l|}{ SM3 } & \multirow[t]{2}{*}{ SEM } & \multicolumn{3}{|c|}{$P$ value } \\
\hline & $\begin{array}{l}\text { Intensive } \\
\text { system }\end{array}$ & $\begin{array}{l}\text { Semi- } \\
\text { intensive } \\
\text { system }\end{array}$ & $\begin{array}{l}\text { Intensive } \\
\text { system }\end{array}$ & $\begin{array}{l}\text { Semi- } \\
\text { intensive } \\
\text { system }\end{array}$ & & S & $\mathrm{H}$ & $\mathrm{SxH}$ \\
\hline Lauric acid (C12:0) & $0.014^{\mathrm{ab}}$ & $0.01^{a}$ & $0.016^{\mathrm{b}}$ & $0.01^{a}$ & 0.00 & ns & ** & ns \\
\hline Myristic acid (C14:0) & 0.31 & 0.25 & 0.31 & 0.30 & 0.04 & ns & ns & ns \\
\hline $\begin{array}{l}\text { Pentadecanoic acid } \\
(\text { C15:0) }\end{array}$ & 0.04 & 0.04 & 0.04 & 0.04 & 0.00 & ns & ns & ns \\
\hline Palmitic acid (C16:0) & 20.87 & 20.80 & 21.33 & 20.97 & 0.61 & ns & ns & ns \\
\hline $\begin{array}{l}\text { Heptadecanoic acid } \\
\text { (C17:0) }\end{array}$ & 0.10 & 0.10 & 0.12 & 0.11 & 0.01 & ns & ns & ns \\
\hline Stearic acid (C18:0) & 7.13 & 8.57 & 7.96 & 7.54 & 1.35 & ns & ns & ns \\
\hline $\begin{array}{l}\text { Arachidic acid } \\
\text { (C20:0) }\end{array}$ & 0.18 & 0.21 & 0.19 & 0.17 & 0.06 & ns & ns & ns \\
\hline $\begin{array}{l}\text { Heneicosanoic acid } \\
\text { (C21:0) }\end{array}$ & 0.01 & 0.02 & 0.01 & 0.01 & 0.00 & ns & ns & ns \\
\hline Behenic acid (C22:0) & 0.11 & 0.13 & 0.11 & 0.09 & 0.05 & ns & ns & ns \\
\hline $\begin{array}{l}\text { Lignoceric acid } \\
\text { (C24:0) }\end{array}$ & 0.07 & 0.08 & 0.07 & 0.05 & 0.03 & ns & ns & ns \\
\hline$\sum$ SFA & 28.83 & 30.19 & 30.16 & 29.29 & 1.34 & ns & ns & ns \\
\hline $\begin{array}{l}\text { Myristoleic acid } \\
(\text { C14:1) }\end{array}$ & 0.03 & 0.03 & 0.02 & 0.03 & 0.01 & ns & ns & * \\
\hline $\begin{array}{l}\text { Palmitoleic acid } \\
\text { (C16:1) }\end{array}$ & 2.24 & 2.04 & 1.83 & 2.27 & 0.34 & ns & ns & ns \\
\hline $\begin{array}{l}\text { Elaidic acid } \\
\text { (C18:1n9t) }\end{array}$ & $0.13^{\mathrm{a}}$ & $0.17^{b}$ & $0.13^{\mathrm{a}}$ & $0.16^{\mathrm{ab}}$ & 0.02 & ns & ** & $\mathrm{ns}$ \\
\hline $\begin{array}{l}\text { Oleic acid } \\
\text { (C18:1n9c) }\end{array}$ & 35.94 & 34.08 & 33.93 & 35.92 & 4.51 & ns & ns & $\mathrm{ns}$ \\
\hline $\begin{array}{l}\text { trans Vaccenic acid } \\
(\mathrm{C} 18: 1 \mathrm{n} 11 \mathrm{t})\end{array}$ & 1.66 & 1.90 & 1.63 & 1.67 & 0.27 & ns & ns & ns \\
\hline $\begin{array}{l}\text { cis Vaccenic acid } \\
\text { (C18:1n11c) }\end{array}$ & $0.08^{\mathrm{a}}$ & $0.32^{\mathrm{b}}$ & $0.17^{\mathrm{ab}}$ & $0.15^{\mathrm{ab}}$ & 0.10 & ns & * & * \\
\hline $\begin{array}{l}\text { Eicosenoic acid } \\
\text { (C20:1n9) }\end{array}$ & 0.24 & 0.23 & 0.22 & 0.21 & 0.01 & * & ns & ns \\
\hline $\begin{array}{l}\text { Erucic acid (C22:1n- } \\
\text { 9) }\end{array}$ & 0.02 & 0.02 & 0.02 & 0.02 & 0.01 & ns & ns & ns \\
\hline
\end{tabular}




\begin{tabular}{|c|c|c|c|c|c|c|c|c|}
\hline$\sum$ MUFA & 40.34 & 38.79 & 37.94 & 40.43 & 4.56 & ns & ns & ns \\
\hline $\begin{array}{l}\text { Linoleic acid } \\
\text { (C18:2n6c) }\end{array}$ & 23.33 & 21.39 & 23.81 & 22.65 & 1.34 & ns & * & ns \\
\hline $\begin{array}{l}\text { trans } \\
\text { Octadecadienoic } \\
\text { acid (C18:2n6) }\end{array}$ & 0.92 & 1.39 & 1.12 & 1.01 & 0.25 & ns & ns & * \\
\hline $\begin{array}{l}\text { y-linolenic acid } \\
(\text { C18:3n-6) }\end{array}$ & 0.08 & 0.07 & 0.09 & 0.08 & 0.01 & ns & ns & ns \\
\hline $\begin{array}{l}\text { Eicosadienoic acid } \\
(\text { C20:2n-6) }\end{array}$ & 0.25 & 0.30 & 0.29 & 0.28 & 0.09 & ns & ns & ns \\
\hline $\begin{array}{l}\text { Dihomo-y-linolenic } \\
\text { acid }(C 20: 3 n-6)\end{array}$ & 0.37 & 0.55 & 0.42 & 0.34 & 0.15 & ns & ns & ns \\
\hline $\begin{array}{l}\text { Arachidonic acid } \\
\text { (C20:4 n-6) }\end{array}$ & 4.47 & 5.84 & 4.68 & 4.48 & 2.35 & ns & ns & ns \\
\hline$\sum$ n-6 PUFA & 29.41 & 29.55 & 30.40 & 28.84 & 3.17 & ns & ns & ns \\
\hline $\begin{array}{l}\text { Alpha-linolenic acid } \\
(\mathrm{C} 18: 3 \mathrm{n}-3)\end{array}$ & 0.98 & 0.84 & 1.00 & 0.99 & 0.10 & ns & ns & ns \\
\hline $\begin{array}{l}\text { Eicosatrienoic acid } \\
(C 20: 3 n-3)\end{array}$ & 0.01 & 0.02 & 0.01 & 0.02 & 0.01 & ns & ns & ns \\
\hline $\begin{array}{l}\text { Eicosapentaenoic } \\
\text { acid (C20:5n-3) }\end{array}$ & 0.09 & 0.11 & 0.08 & 0.09 & 0.03 & ns & ns & ns \\
\hline $\begin{array}{l}\text { Docosapentaenoic } \\
\text { acid (C22:5n-3) }\end{array}$ & 0.24 & 0.32 & 0.27 & 0.24 & 0.11 & ns & ns & ns \\
\hline $\begin{array}{l}\text { Docosahexaenoic } \\
\text { acid (C22:6n-3) }\end{array}$ & 0.11 & 0.19 & 0.14 & 0.11 & 0.07 & ns & ns & ns \\
\hline$\sum$ n-3 PUFA & 1.42 & 1.47 & 1.50 & 1.44 & 0.14 & ns & ns & ns \\
\hline$\sum n-6 / \sum n-3$ PUFA & 20.71 & 20.10 & 20.27 & 20.03 & 0.51 & ns & ns & ns \\
\hline MUFA/SFA & $1.40^{\mathrm{a}}$ & $1.28^{\mathrm{b}}$ & $1.26^{\mathrm{b}}$ & $1.38^{\mathrm{a}}$ & 0.05 & ns & ns & 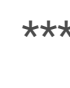 \\
\hline PUFA/SFA & 1.07 & 1.03 & 1.06 & 1.03 & 0.04 & ns & ns & ns \\
\hline UFA/SFA & $2.47^{\mathrm{A}}$ & $2.31^{\mathrm{B}}$ & $2.31^{\mathrm{B}}$ & $2.41^{\mathrm{AB}}$ & 0.06 & ns & ns & 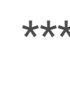 \\
\hline Al & 0.31 & 0.31 & 0.32 & 0.31 & 0.01 & ns & ns & ns \\
\hline TI & $0.72^{a}$ & $0.77^{\mathrm{b}}$ & $0.76^{b}$ & $0.74^{\mathrm{ab}}$ & 0.02 & ns & ns & * \\
\hline$H / H$ & 2.84 & 2.67 & 2.71 & 2.80 & 0.10 & ns & ns & * \\
\hline
\end{tabular}

Data are means and standard error of means (SEM). Within a row, means with a different superscript letter differ $(\mathrm{a}, \mathrm{b}-P<0.05)$. 
STAR 53 = STAR 53 medium hybrid of Pekin duck; SM3 = SM3 heavy hybrid of Pekin duck; $\mathrm{S}=$ duck strain factor; $\mathrm{H}$ = housing factor; $\mathrm{SxH}$ = interaction between duck strain and housing factor; $\mathrm{ns}=$ no significance $(P>0.05) ; * P<0.05 ; \star \star P<0.01$; SFA = saturated fatty acids; MUFA = monounsaturated fatty acids; PUFA = polyunsaturated fatty acids; UFA = unsaturated fatty acids; $\mathrm{Al}=$ atherogenicity index; $\mathrm{TI}=$ thrombogenicity index; $\mathrm{H} / \mathrm{H}=$ hypocholesterolemic to hypercholesterolemic fatty acids ratio.

Table 5 The effect of Pekin duck strain and housing system on fatty acid profile of thighs $(n=6)$ 


\begin{tabular}{|c|c|c|c|c|c|c|c|c|}
\hline \multirow[t]{3}{*}{ Fatty acid } & \multicolumn{8}{|c|}{ Duck strain $(\mathrm{S})$ - Housing system $(\mathrm{H})$} \\
\hline & \multicolumn{2}{|l|}{ STAR 53} & \multicolumn{2}{|l|}{ SM3 } & \multirow[t]{2}{*}{ SEM } & \multicolumn{3}{|c|}{$P$ value } \\
\hline & $\begin{array}{l}\text { Intensive } \\
\text { system }\end{array}$ & $\begin{array}{l}\text { Semi- } \\
\text { intensive } \\
\text { system }\end{array}$ & $\begin{array}{l}\text { Intensive } \\
\text { system }\end{array}$ & $\begin{array}{l}\text { Semi- } \\
\text { intensive } \\
\text { system }\end{array}$ & & S & $\mathrm{H}$ & $\mathrm{SxH}$ \\
\hline Lauric acid (C12:0) & 0.01 & 0.01 & 0.01 & 0.01 & 0.00 & ns & ns & ns \\
\hline Myristic acid (C14:0) & 0.28 & 0.28 & 0.28 & 0.32 & 0.03 & ns & ns & ns \\
\hline $\begin{array}{l}\text { Pentadecanoic acid } \\
(\mathrm{C} 15: 0)\end{array}$ & 0.03 & 0.03 & 0.03 & 0.04 & 0.00 & * & ns & ns \\
\hline Palmitic acid (C16:0) & 18.92 & 19.47 & 18.89 & 20.15 & 0.70 & ns & * & ns \\
\hline $\begin{array}{l}\text { Heptadecanoic acid } \\
\text { (C17:0) }\end{array}$ & 0.09 & 0.09 & 0.10 & 0.09 & 0.01 & ns & * & ns \\
\hline Stearic acid (C18:0) & 7.91 & 8.19 & 7.63 & 6.59 & 0.91 & ns & ns & ns \\
\hline $\begin{array}{l}\text { Arachidic acid } \\
(\mathrm{C} 20: 0)\end{array}$ & 0.15 & 0.16 & 0.14 & 0.11 & 0.03 & ns & ns & ns \\
\hline $\begin{array}{l}\text { Heneicosanoic acid } \\
\text { (C21:0) }\end{array}$ & 0.01 & 0.01 & 0.01 & 0.01 & 0.00 & ns & ns & ns \\
\hline Behenic acid (C22:0) & 0.06 & 0.07 & 0.06 & 0.11 & 0.07 & ns & ns & ns \\
\hline $\begin{array}{l}\text { Lignoceric acid } \\
\text { (C24:0) }\end{array}$ & 0.03 & 0.04 & 0.03 & 0.02 & 0.01 & ns & ns & ns \\
\hline$\sum$ SFA & 27.49 & 28.35 & 27.19 & 27.45 & 0.70 & ns & ns & ns \\
\hline $\begin{array}{l}\text { Myristoleic acid } \\
\text { (C14:1) }\end{array}$ & 0.04 & 0.04 & 0.03 & 0.04 & 0.00 & ns & ns & ns \\
\hline $\begin{array}{l}\text { Palmitoleic acid } \\
(\mathrm{C} 16: 1)\end{array}$ & 2.47 & 2.72 & 2.41 & 2.72 & 0.23 & ns & * & ns \\
\hline $\begin{array}{l}\text { Elaidic acid } \\
(\mathrm{C} 18: 1 \mathrm{n} 9 \mathrm{t})\end{array}$ & $0.19^{a}$ & $0.22^{\mathrm{a}}$ & $0.18^{a b}$ & $0.13^{b}$ & 0.03 & $\star \star$ & ns & $\star \star$ \\
\hline Oleic acid (C18:1n9c) & 39.28 & 40.79 & 40.53 & 42.24 & 2.50 & ns & ns & ns \\
\hline $\begin{array}{l}\text { trans Vaccenic acid } \\
\text { (C18:1n11t) }\end{array}$ & $1.62^{\mathrm{A}}$ & $1.19^{\mathrm{A}}$ & $1.08^{\mathrm{A}}$ & $0.22^{\mathrm{B}}$ & 0.38 & $\star \star \star ~$ & ** & ns \\
\hline $\begin{array}{l}\text { cis Vaccenic acid } \\
\text { (C18:1n11c) }\end{array}$ & 0.32 & 0.51 & 0.35 & 0.31 & 0.26 & ns & ns & ns \\
\hline $\begin{array}{l}\text { Eicosenoic acid } \\
\text { (C20:1n9) }\end{array}$ & 0.23 & 0.24 & 0.25 & 0.25 & 0.01 & ** & ns & ns \\
\hline $\begin{array}{l}\text { Erucic acid (C22:1n- } \\
\text { 9) }\end{array}$ & 0.01 & 0.01 & 0.01 & 0.01 & 0.00 & ns & ns & ns \\
\hline$\sum M U F A$ & 44.17 & 45.73 & 44.86 & 45.93 & 2.20 & ns & ns & ns \\
\hline
\end{tabular}




\begin{tabular}{|c|c|c|c|c|c|c|c|c|}
\hline $\begin{array}{l}\text { Linoleic acid } \\
\text { (C18:2n6c) }\end{array}$ & $22.22^{\mathrm{ab}}$ & $20.12^{\mathrm{a}}$ & $22.44^{\mathrm{b}}$ & $22.44^{\mathrm{b}}$ & 1.07 & * & ns & ns \\
\hline $\begin{array}{l}\text { total trans } \\
\text { Octadecadienoic acid } \\
\text { (C18:2n6) }\end{array}$ & $1.03^{\mathrm{A}}$ & $1.03^{\mathrm{A}}$ & $0.90^{\mathrm{AB}}$ & $0.65^{\mathrm{B}}$ & 0.15 & $\star \star$ & ns & ns \\
\hline $\begin{array}{l}\text { Y-linolenic acid } \\
(\text { C18:3n-6) }\end{array}$ & 0.07 & 0.06 & 0.07 & 0.07 & 0.01 & ns & ns & ns \\
\hline $\begin{array}{l}\text { Eicosadienoic acid } \\
(\text { C20:2n-6) }\end{array}$ & 0.18 & 0.17 & 0.18 & 0.15 & 0.03 & ns & ns & ns \\
\hline $\begin{array}{l}\text { Dihomo- } y \text {-linolenic } \\
\text { acid (C20:3 n-6) }\end{array}$ & 0.26 & 0.29 & 0.25 & 0.19 & 0.06 & ns & ns & ns \\
\hline $\begin{array}{l}\text { Arachidonic acid } \\
\text { (C20:4 n-6) }\end{array}$ & 3.26 & 3.08 & 2.77 & 1.90 & 0.82 & ns & ns & ns \\
\hline$\sum$ n-6 PUFA & 27.03 & 24.74 & 26.60 & 25.39 & 1.77 & ns & ns & ns \\
\hline $\begin{array}{l}\text { Alpha-linolenic acid } \\
(\mathrm{C} 18: 3 \mathrm{n}-3)\end{array}$ & $0.89^{A B}$ & $0.81^{A}$ & $0.98^{\mathrm{B}}$ & $0.96^{\mathrm{B}}$ & 0.06 & $\star \star \star$ & ns & ns \\
\hline $\begin{array}{l}\text { Eicosatrienoic acid } \\
(\text { C20:3 n-3) }\end{array}$ & 0.01 & 0.01 & 0.01 & 0.01 & 0.00 & ns & ns & ns \\
\hline $\begin{array}{l}\text { Eicosapentaenoic } \\
\text { acid (C20:5n-3) }\end{array}$ & 0.07 & 0.06 & 0.06 & 0.06 & 0.01 & ns & ns & ns \\
\hline $\begin{array}{l}\text { Docosapentaenoic } \\
\text { acid (C22:5n-3) }\end{array}$ & 0.24 & 0.19 & 0.20 & 0.14 & 0.05 & ns & ns & ns \\
\hline $\begin{array}{l}\text { Docosahexaenoic } \\
\text { acid (C22:6n-3) }\end{array}$ & 0.11 & 0.11 & 0.11 & 0.07 & 0.03 & ns & ns & ns \\
\hline$\sum$ n-3 PUFA & 1.31 & 1.18 & 1.35 & 1.23 & 0.10 & ns & * & ns \\
\hline$\sum n-6 / \sum n-3$ PUFA & $20.63^{a b}$ & $20.96^{a}$ & $19.70^{\mathrm{b}}$ & $20.64^{\mathrm{ab}}$ & 0.61 & ns & * & ns \\
\hline MUFA/SFA & 1.61 & 1.61 & 1.65 & 1.67 & 0.06 & ns & ns & ns \\
\hline PUFA/SFA & $1.03^{\mathrm{a}}$ & $0.91^{\mathrm{b}}$ & $1.03^{\mathrm{a}}$ & $0.97^{c}$ & 0.02 & * & 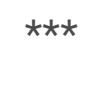 & * \\
\hline UFA/SFA & 2.64 & 2.53 & 2.68 & 2.64 & 0.08 & ns & ns & ns \\
\hline $\mathrm{Al}$ & 0.28 & 0.29 & 0.28 & 0.30 & 0.01 & ns & ** & ns \\
\hline TI & 0.69 & 0.72 & 0.67 & 0.69 & 0.03 & ns & ns & ns \\
\hline $\mathrm{H} / \mathrm{H}$ & 3.25 & 3.12 & 3.33 & 3.21 & 0.11 & ns & * & ns \\
\hline
\end{tabular}

Data are means and standard error of means (SEM). Within a row, means with a different superscript letter differ (a, b, c $-P<0.05 ; A, B-P<0.01)$. STAR $53=$ STAR 53 medium hybrid of Pekin duck; SM3 = SM3 heavy hybrid of Pekin duck; $\mathrm{S}=$ duck strain factor; $\mathrm{H}=$ housing factor; $\mathrm{SxH}=$ interaction between duck strain and housing factor; ns $=$ no significance $(P>0.05) ;{ }^{*} P<0.05 ;{ }^{\star \star} P<0.01 ; \star \star \star P<0.001$; SFA $=$ 
saturated fatty acids; MUFA = monounsaturated fatty acids; PUFA = polyunsaturated fatty acids; UFA = unsaturated fatty acids; $\mathrm{Al}=$ atherogenicity index; $\mathrm{TI}=$ thrombogenicity index; $\mathrm{H} / \mathrm{H}=$ hypocholesterolemic to hypercholesterolemic fatty acids ratio.

Table 6 The effect of Pekin duck strain and housing system on fatty acid profile of breasts and thighs $(n=6)$ 


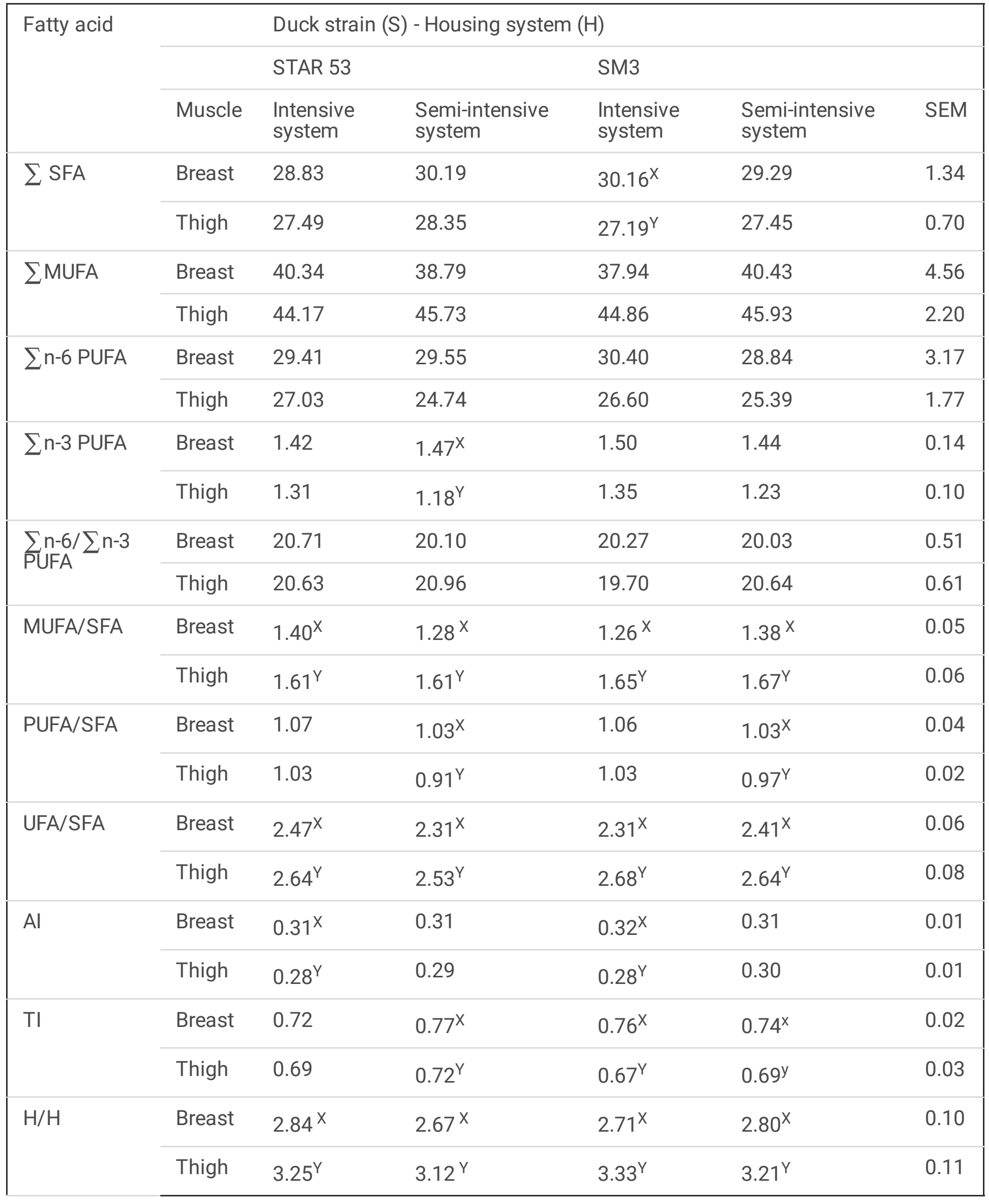

Data are means and standard error of means (SEM). Within a column of each parameter, means with a different superscript letter differ $(X, y-P<0.05 ; X, Y-P<0.01)$. 
STAR 53 = STAR 53 medium hybrid of Pekin duck; SM3 = SM3 heavy hybrid of Pekin duck; SFA = saturated fatty acids; MUFA = monounsaturated fatty acids; PUFA = polyunsaturated fatty acids; UFA = unsaturated fatty acids; $\mathrm{Al}=$ atherogenicity index; $\mathrm{TI}=$ thrombogenicity index; $\mathrm{H} / \mathrm{H}=$ hypocholesterolemic to hypercholesterolemic fatty acids ratio. 